\title{
Users' Assessment of Arabic-Spanish Retour: Non- Native Accent, Fidelity and Accuracy Criteria
}

\author{
Bachir Mahyub Rayaa, PhD \\ University of Granada, Spain
}

Doi: 10.19044/ejes.v6no1a3

URL:http://dx.doi.org/10.19044/ejes.v6no1a3

\begin{abstract}
Arabic-Spanish simultaneous interpreting (AR-SP SI) in Spain and the Arab world is, on the whole, carried out by native Arabic speakers. Specifically, 87.5\% of AR-SP SI interpreters in Spain have Arabic as A language and Spanish as language B.

Given this peculiarity, for this linguistic combination it was interesting, as well as novel, to analyse users' assessment of AR-SP retour quality and its acceptability, by studying three quality criterion, two relating to content - the fidelity and accuracy in the delivery of the source speech - and one relating to form - the non-native accent of the interpreter (NNAI) in Spanish. To this end, this mixed quantitative and qualitative study sounded out the opinion of 50 users by filling out a questionnaire. After watching a 30-minute conference video interpreted by a native Arabic interpreter, subjects completed 6 mixed close-ended and open-ended questions related to the three aforementioned criterions.

The results show that the wide majority of users evaluated the source speech delivery as good comprehension of the content, and that NNAI did not seem to have a negative impact on their overall evaluation.
\end{abstract}

Keywords: User assessment; Arabic-Spanish retour; Interpreting fidelity; Interpreting accuracy; Non-native accent.

\section{Introduction: The state of the question}

In recent decades, Arabic-Spanish interpreting has witnessed a large increase, in all of its modalities. Nevertheless, this demand experienced in the professional sphere has not been accompanied by intense research activity in the field of interpreting, although there are exceptions such as the growing number of studies on AR-SP public services interpreting (Feria 2007, Taibi 2007 and Ortega-Herráez 2010, among others), and the appearance of the first works on AR-SP conference interpreting (Mahyub Rayaa 2013 and 2015, Mahyub Rayaa \& Zarrouk 2013 and 2017). In the field of interpreting quality 
assessment, despite three recent studies being had come to light (Barbato 2014, Mahyub Rayaa 2017a and 2017b); the need for empirical research is evident. This same reality could be applicable for other combinations that include Arabic, such as Arabic-English (Al-Salman \& Al-Khanji 2002) or Arabic-French (Hassan 2009), which are much more disseminated and carried out than Arabic-Spanish. Amongst the factors that could contribute to this scarcity of research are, on the one hand, the academic community that works in the field of the Arabic language and its translation does not practice conference interpretation professionally, and on the other, the lack of academic and research experience in the collective of interpreters who carry it out. As can be seen, the reasons are very similar to the state of research on interpretation at its beginnings (Pöchhacker 2004).

In addition to the foregoing, amongst the reasons that have brought me to embark on this study is the fact the professional demand is almost always covered by interpreters who in general have Arabic as their A language and Spanish as their B language. The study of professional market undertaken by Mahyub Rayaa (2015) within the framework of his $\mathrm{PhD}$ thesis on the teaching and professional practice of SI showed that $87.5 \%$ of AR-SP conference interpreters working in Spain have Arabic as their A language and Spanish as their B language. In addition, the language profile of AR-SP translation students is very heterogeneous (Feria García 2014: 203-204).

Furthermore, in the multilingual events held in the institutional and free markets in Spain, when Arabic and other languages are employed, the pivot language is nearly always Spanish. Seldom is there a resort to one-way booths1 with interpreters of other language combinations (e.g. AR $>$ EN or $\mathrm{AR}>\mathrm{FR}$ ), rather, there is a tendency to opt for AR $<>\mathrm{SP}$ two-way booths. This need means that there is a forced dependence on the Spanish relay from the Arabic booth. In this regard, it is no secret to say that this relay is not always perceived with satisfaction by colleagues in the other booths.

In view of these peculiarities of the AR-SP booth, an analysis of the AR-SP retour perceived quality could be revealing, beginning with the users' evaluation, who are the final interpreting recipients. In future stages this line could be expanded with the study of the evaluation of interpreters of other language combinations as recipients of the Arabic booth relay.

Therefore, this paper is in line with research that study users' assessment of the quality of SI. This line has been tackled in depth in recent decades by a number of authors (Bühler 1986, Kurz 1989, Collados Aís 1998, Pradas Macías 2003, Collados Aís et al. 2007, García Becerra et al. 2013, etc.).

1 Booths which deliver interpretation just in one direction, e.g. from English into Arabic, but not the contrary. 
Following the line of prior studies of Mahyub Rayaa (2017a and 2017b), the aim of this paper is to provide a new contribution to the state of the question of research in AR-SP SI perceived quality, expanding the study sample and varying the profile of users, as well as stressing two of the most important criterion in terms of content quality, and best valued by users and interpreters (Bühler 1986, Fernández Sánchez et al. 2007, Pradas Macías et al., 2007): fidelity (correct delivery) and accuracy (complete delivery) of the source speech. Although previous literature coincides in putting more importance on parameters relating to content than those relating to form, the formal criteria non-native accent of the interpreter (NNAI) (Bühler 1986, Cheung 2003 and Stévaux 2007, amongst others), was included given its relevance for retour, the subject at hand.

\section{Working hypothesis and objectives}

In light of the aforementioned works, it is the aim of this study to start from the following hypothesis: users of interpreting would give a bad overall evaluation of an AR-SP retour when the NNAI is pronounced, thus affecting the source speech delivery made by the interpreter. In addition to ascertaining whether this hypothesis is correct or not, the following objectives are sought: To analyse how users perceive and evaluate the quality of AR-SP retour in overall terms.

To find out how they evaluate the NNAI criteria as well as the interpreting fidelity and accuracy.

To ascertain how the NNAI has an impact in the event of being pronounced in the users' assessment of the interpretation content.

Ascertain whether the presence of a pronounced NNAI leads users to evaluate negatively the interpretation general quality.

\section{Material and method}

This study applies a mixed quantitative and qualitative method. 50 users were sounded out by running a questionnaire2. In order to achieve the aforementioned goals, users were asked to answer 6 mixed close-ended and open-ended questions after watching a 30 minute conference video interpreted into Spanish by a native Arabic interpreter.

A 30 minutes event video with the audio of a real AR-SP SI3 was used. It involves the presentation of a novel, entitled in Spanish A escondidas, by its author Sonallah Ibrahim (Egypt, 1938). The event was held in the Casa Árabe

2 See here: <https://figshare.com/s/316fb1ef80d70844fea5>

3 Available at: <https://www.youtube.com/watch?v=607dVVxoQPA> Video segment from 12:30 to 41:22 minutes. Last view: 2 November 2018 
(Madrid), in June 13th 2013. The original audio of the video was superimposed by the AR-SP SI. The interpretation was carried out by a single interpreter with Arabic as A language and Spanish as B. He is Egyptian, as is the speaker, settled in Spain and boasts over 20 years' professional experience as a SP-AR conference interpreter, both direct and retour. The SI was selected for the study because of the NNAI, the directionality of the interpretation and the literary theme of the event, so a high register in Spanish is needed. These three criteria are addressed in the study.

The viewing of the video and the questionnaire were carried out in two sessions in the Faculties of Translation and Interpreting (May $9^{\text {th }} 2017$ ) and Philosophy and Arts (May 11 ${ }^{\text {th }}$ 2017), both at the University of Granada. Immediately following the viewing, participants were asked to respond to the questionnaire in the most possible detail. Lastly, the answers were put into an Excel worksheet for their subsequent statistical treatment.

\section{Subjects}

50 users took part in the study. All have Spanish as a first language (A). Notwithstanding, of the total number of users who participated, 20 (40\%) also have knowledge of Arabic as a B or C language. 58\% were studying or had completed a Bachelor's degree in translation and interpreting; 22\% philology; and the remaining $20 \%$ has no University studies. The average age of the participants is 24.2 years old. $71.5 \%$ are women and $28.5 \%$, men.

\section{Results}

The results obtained were then divided into different sections in accordance with the questions formulated to users. The responses to the open questions were summarised to provide them greater clarity.

\section{Overall evaluation of the interpretation}

The objective of the first question was to find out how the users would grade the interpretation just after having heard it, in order to get their first impression. The majority of users (58\%) evaluated it as good, followed by very good (22\%) and average (20\%). None assessed it as poor or very poor. The users who elaborated on their evaluation justified their response with:

\begin{tabular}{|l|l|}
\hline Comment & No. users \\
\hline Good & \\
\hline Good comprehension & 21 \\
\hline Although the accent is pronounced & 5 \\
\hline Good voice & 4 \\
\hline Although there are pauses and hesitation & 3 \\
\hline Very good & \\
\hline Good fluency & 3 \\
\hline Very good. Good choice of vocabulary & 3 \\
\hline
\end{tabular}




\begin{tabular}{|l|l|}
\hline Average & \\
\hline Not a native Spanish speaker (lack of naturalness) & 6 \\
\hline Lack of coherence and cohesion & 3 \\
\hline Lack of fluency & 3 \\
\hline Monotonous intonation & 1 \\
\hline
\end{tabular}

Table 1. Additional comments to the overall evaluation of the interpretation.

\section{Perception of the interpreter's non-native accent}

The following question was regarding how the users would rate the NNAI. $76 \%$ of the participants perceived the accent of the interpreter as pronounced or very pronounced. The total results were as in showed in figure 1:

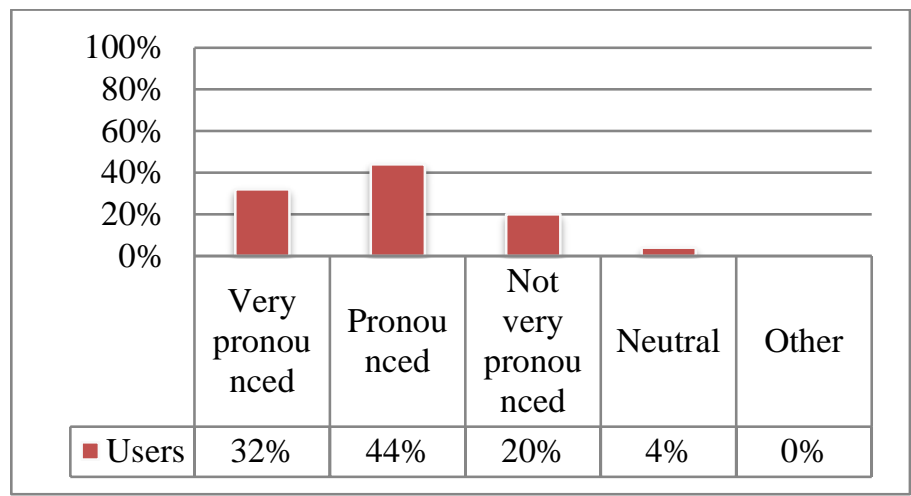

Figure 1. Perception of the interpreter's non-native accent.

Furthermore, I wanted to ask whether the NNAI had impeded their comprehension of the discourse according to their perception. More than a half of the users (32 subjects) perceived that it did not, whereas over a third (18) said it did.

\section{Evaluation of the Interpreting fidelity}

In response to the question of how they would rate the delivery of the message on the part of the interpreter, the majority of users evaluated it as correct (76\%), followed by not very correct (20\%) and very correct (4\%). None assessed it as incorrect. The users who justified their response indicated:

\begin{tabular}{|l|l|}
\hline Comment & No. users \\
\hline Correct & \\
\hline Good comprehension of the source speech or parts of it & 9 \\
\hline Coherence and cohesion & 2 \\
\hline Confidence transmitted by the interpreter & 1 \\
\hline Very correct & \\
\hline Appropriate vocabulary & 2 \\
\hline Good Fluency & 1 \\
\hline Voice of interpreter & 1 \\
\hline Not very correct & \\
\hline
\end{tabular}




\begin{tabular}{|l|l|}
\hline Literality & 4 \\
\hline Lack of fluency & 2 \\
\hline Inappropriate vocabulary & 1 \\
\hline Tone of interpreter & 1 \\
\hline Inadequate register & 1 \\
\hline Lack of clarity & 1 \\
\hline Lack of confidence & 1 \\
\hline Others & \\
\hline Cannot check it & 2 \\
\hline
\end{tabular}

Table 2. Additional comments to the perception of the interpreting fidelity.

In this regard, I wanted to ascertain if there are other elements that make comprehension difficult. $62 \%$ of users (31) thought they did, whereas $38 \%$ (19) thought the opposite. The users who provided justification to their response indicated:

\begin{tabular}{|l|l|}
\hline Comment & No. users \\
\hline Yes & \\
\hline Not very natural syntactic structure & 9 \\
\hline Accent & 6 \\
\hline Incorrect collocations in Spanish & 5 \\
\hline Not very natural vocabulary & 5 \\
\hline Pauses & 3 \\
\hline No & \\
\hline Good comprehension & 5 \\
\hline Appropriate vocabulary & 2 \\
\hline
\end{tabular}

Table 3. Other elements that make comprehension difficult.

\section{Interpreting accuracy (complete delivery of source speech)}

Asked whether the interpreter completely transmitted the source speech, the percentage of users who responded affirmatively, although slightly lower compared to the previous question on interpreting fidelity, was still a majority of $70 \%$ of respondents. 20\% responded "no" and 10\% does not know. The users who justified their response indicated the difficulty in producing an objective judgment; however, except five users (see Figure 5), they all evaluated this criteria and justified it as follows in table 4:

\begin{tabular}{|l|l|}
\hline Comment & No. users \\
\hline Yes, it was accurate. & \\
\hline Although I am not familiar with the Arabic language & 11 \\
\hline Good fluency (no pauses) & 7 \\
\hline Confidence transmitted by the interpreter & 4 \\
\hline Coherence & 3 \\
\hline Good comprehension of the message or parts of it & 3 \\
\hline Appropriate vocabulary & 1 \\
\hline Although lack of confidence perceived in the interpreter & 1 \\
\hline No, it wasn't accurate. & \\
\hline Lack of coherence and cohesion & 5 \\
\hline
\end{tabular}




\begin{tabular}{|l|l|}
\hline Lack of fluency & 4 \\
\hline Loss of nuances & 3 \\
\hline Monotonous intonation & 2 \\
\hline Inappropriate vocabulary & 2 \\
\hline Literality & 2 \\
\hline Change of source meaning & 1 \\
\hline
\end{tabular}

Table 4. Justification regarding interpreting accuracy.

\section{Analysis and discussion}

The results collected in the previous sections are analysed and discussed below.

\section{Overall evaluation}

The data obtained indicate that no user evaluated the interpretation as poor or very poor. These results collected in the first question with the aim of finding out the user's first impressions endorse the retour, in which the NNAI is very pronounced (see Figure 1). In this manner, this overall evaluation would rule out my initial hypothesis while supporting the initial results of Mahyub Rayaa (2017a). Additionally, it would indicate a possible acceptability of AR-SP retour, at least amongst the group of users who participated in the study.

"Good comprehension" of the interpretation is by far the justification most provided by users for their positive evaluation, which could be interpreted as a prevalence of the content transmitted by the interpreter to the form in which such content is presented, in line with Marrone (1993: 38).

In this way, the NNAI, despite being perceived by six users as "nonnative in Spanish" or "lack of naturalness", does not necessarily imply an overall negative evaluation (cf. Cheung 2003). Other factors, such as fluency and appropriate vocabulary, are provided as a justification of some "very good" assessments. Notwithstanding, amongst those who gave a rating of "average", lack of fluency was also indicated, but above all, the lack of naturalness in the interpretation; that is, the presence of calques and structures that were not very idiomatic, as well as lack of coherence. The elements of Spanish (syntactic structure, collocations, etc.) could also make the comprehension of the source speech more difficult.

\section{Evaluation of the non-native accent}

The data obtained in this section justify the choice of the interpretation analysed, given that 76\% (38) of users perceived the NNAI as pronounced or very pronounced. However, in view of the results obtained in this and the previous section, and despite the users' subjectivity, the conclusion was that the NNAI did not have a negative influence on the overall rating provided by the users themselves, nor did it reduce the intelligibility or comprehension of 
the source speech (see Figure 3). This detail would again rule out the starting hypothesis while reinforcing a number of statements in the previous literature (Baigorri Jalón 2000: 292 and Martin 2003: 432, amongst others), although they do not specifically refer to the Arabic accent in Spanish, and would increase the results of Mahyub Rayaa (2017b: 16-19) on the use of Spanish in AR-SP retour and its influence on the perception of interpreting quality. For Baigorri Jalón (2000: 292) a certain degree of non-native accent would be bearable and up to a certain point constitutes an exotic feature attributable to polyglots. In this regard, one should not forget the fact that in this study the speaker and the interpreter come from the same country, Egypt. So what Martin indicates could be a point in favor of the NNAI. In fact, in dubbing of TV reports and programs i.e. BBC, a voice over of the same accent of the speaker is often used.

As outlined in the overall evaluation of the users surveyed, it cannot be concluded that they evaluate an AR-SP IS with NNAI negatively, as the data obtained by Stévaux (2007: 35) and Cheung (2003: 96) seem to indicate. Always applying due caution, no relevant results that associate NNAI with unintelligibility were found. It is convenient, however, to investigate the fact that for 36\% (18), the NNAI did have an effect on the comprehension of the source speech, what could be interpreted as a possible distraction, in line with Donovan (2004: 210). Focusing more on the users' linguistic profile, we can see a greater tolerance of the NNAI amongst the group that has some knowledge of the Arabic language (see "subjects" above). This could be interpreted as a criterion for users being identified with their foreign language (Brisau et al. 1994: 84-90, apud Stévaux 2007: 22). In this regard, criterion such as the interpreter's pleasant voice and their fluency could have had an influence on these users by causing a positive impact and/or softening the NNAI effect (see Table 1).

\section{Interpreting fidelity}

The great majority of users (76\%) rated the source speech delivery as correct, although $42 \%$ (21) of these did not give justification for this (see Table 2). Despite the fact that this percentage could indicate a lack of capacity to providing an accurate justification regarding content, only two users expressly stated it thus. 58\% (29) who justified their answer give a variety of positive and negative reasons, some on content-related aspects such as good comprehension, coherence and cohesion, or the literality of the interpretation, and others on form-related aspects such as interpreter's fluency and confidence. The data obtained clearly show that all of the users provided an opinion on how they perceived the interpretation. These opinions coincide with the results obtained by Collados Aís (1998: 187) and Fernández Sánchez et al (2007: 103), where no participant stopped evaluating this criterion. 
Therefore, there is still a partial incapacity on the part of the users when providing reasoned opinions based on content, as pointed out at the beginning of this paper.

\section{Interpreting accuracy}

From the results obtained in this section, particular attention may be drawn to the fact that $70 \%$ (35) of users evaluated the source speech delivery as complete, and 11 of them indicated their lack of capacity to do so despite the evaluation given (see Table 4). Furthermore, in this same section there was an increase in the number of users who indicated their reservations in relation to confidently saying whether the interpreter completely transmitted the source speech, arguing that they did not know Arabic, and therefore their evaluation cannot be objective.

In this regard, differences can be appreciated depending on whether or not the users understand Arabic. Thus, amongst the group of users who do not understand this language, the percentage of those who think that the interpreter completely transmitted the source speech increases to $92 \%$ of this subgroup, although some of them expressed a certain contradiction on arguing in the justification that they cannot know it with precision. This contradiction is not so obvious amongst the group of those who understood Arabic, which would indicate the possibility of some users attempting to capture fragments of the source speech (e.g. following décalage pauses) and comparing them with the interpretation (see Table 4).

In addition, this criterion seems to interact positively and negatively with other non-verbal parameters closely linked to it, such as aspects of fluency as the absence/presence of pauses and confidence showed by the interpreter. This gives credence to the conclusions of previous works (Pradas Macías 2003, Pradas Macías et al. 2007: 120 and Mahyub Rayaa 2017a). Neither can the appearance of the coherence factor in this section be ignored, either irritating or as a source speech delivery facilitator (see Table 4), more so when involving a criteria often identified with the interpreting fidelity (Sánchez Fernández et al. 2007: 89).

\section{Conclusions}

Overall, the users positively evaluated the AR-SP retour. The fidelity of the AR-SP retour with a pronounced NNAI was perceived by the users as good, given that in their opinion the interpreter provided a good comprehension. The results indicate that the intelligibility of the interpretation (good comprehension) is the most influential factor on the overall evaluation of the users, being prevailing over formal criterion such as NNAI, even when this is pronounced. The NNAI, identified by the majority as pronounced or very pronounced, did not negatively influence the overall AR-SP retour 
evaluation which, together with the previous conclusions, would rule out the initial hypothesis. Practically all of the users provided assessment on the interpreting fidelity and accuracy, although they lacked sufficient factors to be able to provide a reasoned opinion on these criteria. This would give credence to the conclusions of the previous literature (Gile 1995 and Pradas Macías et al. 2007: 104). Furthermore, a considerable number of users were aware of their inability to judge the interpreting fidelity and accuracy, either due to not speaking the source language, or not having access to the source speech. Despite this fact, the users assessed the content when required to do so ( $c f$. Collados Aís 1998: 187). When asked about the complete delivery of the source speech (accuracy), users positively and negatively justified their evaluations with formal elements linked to the delivery itself such as the fluency, pauses and confidence of the interpreter, in line with Pradas Macías et al. (2007: 120) and Fernández Sánchez et al. (2007: 122), amongst others. However, the users did not just justify their responses with formal aspects. They also based their evaluation on the content through criteria such as coherence of the interpretation, structure and vocabulary, which are more closely connected to the content of the source speech. This extent supports the initial conclusions of Mahyub Rayaa (2017a). In this respect, it can be concluded that the user's assessment is not definitive, nor does it follow a single pattern, being very subjective and arbitrary, in line with the indications of previous studies.

Given the different interpretations that can be drawn from the results obtained, caution is recommended. In order to validate or reject these conclusions, there is a need for future research.

\section{References:}

1. Al-Salman, S. y Al-Khanji, R. (2002). The Native Language Factor in Simultaneous Interpretation in an Arabic/English Context, Meta 47:4, 607-626.

2. Baigorri Jalón, J. (2000). La interpretación de conferencias: El nacimiento de una profesión: De París a Nuremberg. Granada: Comares.

3. Barbato, L. (2014). La credibilidad de la voz del intérprete en la administración de justicia (Estudio de caso de la voz del intérprete de Rabei Osman Sayad 'El Egipcio' en el juicio del 11-M), Transfer 9:12, 127-149.

4. Bühler, H. (1986). Linguistic (semantic) and extralinguistic (pragmatic) criteria for the evaluation of conference interpretation and interpreters. Multilingua 5: 4, 231-235.

5. Cheung, A. (2003). Does accent matter? The impact of accent in simultaneous interpretation into Mandarin and Cantonese on perceived 
performance quality and listener satisfaction level. In A. Collados Aís, M. M. Fernández Sánchez \& D. Gile (eds.). Granada: Comares.

6. Collados Aís, Á. (1998). La evaluación de la calidad de la interpretación. La importancia de la comunicación no verbal. Granada: Comares.

7. Collados Aís, A. et al. (eds.) (2003). La evaluación de la calidad de la interpretación: docencia y profesión. Granada: Comares.

8. Collados Aís, Á. et al. (eds.) (2007). La evaluación de la calidad en interpretación simultánea: parámetros de incidencia. Granada: Comares.

9. Collados Aís, A., Fernández Sánchez, M. M. \& Gile, D. (eds.) (2003). La evaluación de la calidad en interpretación: investigación. Granada: Comares.

10. Donovan, C. (2004). European masters project group. Teaching simultaneous interpretation into a B language. Preliminary findings. Interpreting, 6:2, 205-216.

11. Feria García, M. C. (2007). La interpretación judicial y la traducción jurada árabe-español en Málaga durante los años noventa. Puentes 8, 25-32.

12. Feria García, M. C. (2014). Planning the Acquisition and Enhancement of Language Skills for Translation and Interpreting Trainees: The Case of Arabic. In V. Aguilar et al. (eds.), Arabele 2012: Teaching and Learning the Arabic Language (pp. 197-220). Murcia: Universidad de Murcia.

13. Fernández Sánchez, M. M. et al. (2007). La incidencia del parámetro transmisión correcta del discurso original (pp. 89-104). In A. Collados Aís et al. (eds.). Granada: Comares.

14. García Becerra, O., Pradas Macías E. M., \& Barranco-Droege, R. (eds.) (2013). Quality in interpreting: widening the scope. Granada: Comares.

15. Gile, D. (1995). Fidelity assessment in consecutive interpretation: An experiment. Target, 7: 1, 151-164.

16. Hassan, F. (2009). Le débat sur la spécificité de l’interprétation par langues et l'interprétation arabe-français (Doctoral dissertation, Université Lumière Lyon 2, France).

17. Kurz, I. (1989). Conference interpreting user expectations. In D. Hammond (ed.). Coming of Age (pp. 143-148). Medford: Learned information.

18. Mahyub Rayaa, B. (2013). La interpretación simultánea árabe-español y sus peculiaridades: docencia y profesión. Estudio piloto. In O. García Becerra, E. M. Pradas Macías \& R. Barranco-Droege (eds.). 
Quality in interpreting: widening the scope. Granada (pp. 337-357). Granada: Comares.

19. Mahyub Rayaa, B., (2015). La interpretación simultánea árabe-español y sus peculiaridades. Docencia y profesión (Doctoral dissertation, University of Granada). Available from Digibug Thesis database. (URI: http://hdl.handle.net/10481/40099).

20. Mahyub Rayaa, B. (2017a). La evaluación del retour en interpretación simultánea árabe-español: transmisión del discurso original. European Scientific Journal, 13:11, 261-279. doi: 10.19044/esj.2017.v13n11p261

21. Mahyub Rayaa, B. (2017b). Directionality assessment in ArabicSpanish Simultaneous Interpreting: The Use of Spanish. European Journal of Social Sciences, 55:1, 12-26.

22. Marrone, S. (1993). Quality: a shared objective. The Interpreters' Newsletter, 5, 35-41.

23. Martin, A. (2003). La direccionalidad y la interpretación: Epílogo. In D. Kelly et al. La direccionalidad en traducción e interpretación. Perspectivas teóricas, profesionales y didácticas (pp. 427-433). Granada: Atrio.

24. Moser-Mercer, B., Künzli, A., \& Korac, M. (1998). Prolonged turns in interpreting: Effects on quality, physiological and psychological stress (pilot study). Interpreting 3:1, 47-64.

25. Ortega-Herráez, J. M. (2010). Interpretar para la Justicia. Granada: Comares.

26. Pöchhacker, F. (2004). Introducing Interpreting Studies. London: Routledge.

27. Pradas Macías, E. M. (2003). Repercusión del intraparametro pausas silenciosas en la fluidez: Influencia en las expectativas y en la evaluación de la calidad en interpretación simultánea (Doctoral dissertation, University of Granada, Spain).

28. Pradas Macías, E. M., Collados Aís, A., \& Fernández Sánchez, M. M. (2007). La incidencia del parámetro transmisión correcta del discurso original (pp. 105-122). In A. Collados Aís et al. (eds.). Granada: Comares.

29. Stévaux, E. et al. (2007). La incidencia del parámetro acento. In A. Collados Aís et al. (eds.). La evaluación de la calidad en interpretación simultánea: parámetros de incidencia (pp. 17-35). Granada: Comares.

30. Taibi, M. (2007). El árabe en el ámbito de la traducción e interpretación en los Servicios Públicos. Puentes 8, 5-10 